\title{
ORIGINAL
}

\section{Synthesis and Properties of Destructible Anionic Surfactants with a 1,3-Dioxolane Ring and Their Use as Emulsifier for Emulsion Polymerization}

\author{
Shingo Yamamura*, Masaki Nakamura*, Kiyoshi Kasai**, \\ Hozumi SATo**, and Tokuji TAKEDA* \\ * Osaka Municipal Technical Research Institute \\ (1-6-50, Morinomiya, Joto-ku, Osaka-shi, ₹ 536) \\ ** Emulsion Development Laboratory, Japan Synthetic Rubber Co., Ltd. \\ (100, Kawajiri-cho, Yokkaichi-shi, Mie-ken, T 510)
}

Destructible anionic surfactants with a 1,3-dioxolane ring were prepared and their surface properties determined. These novel surfactants contain a sulfonate group as the anionic hydrophile, and readily decompose under weakly acidic conditions. As surfactants for emulsion polymerization reactions, they are considerably superior to the conventional surfactants which give polymers containing higher contents of metals than the above surfactants.

\section{Introduction}

Application of surfactants to organic synthesis has appeared as a convenient method for overcoming the problem of reacting a water-insoluble organic compound with a water-soluble reagent $t^{1,2)}$. Because of their troublesome emulsions formed by the surfactants, however, we have frequently been confronted with the difficulty of separating desired products from the emulsions. In order to solve this problem, the isolation of the desired products has traditionally been carried out by the addition of an appropriate metal salt. For example, polymerization in the presence of surfactants is a useful industrial process, and for the purpose of breaking the emulsion, metal salt such as calcium or magnesium salt has been added after the completion of the polymerization reaction. But this procedure often debases the water-resistance and the electrical insulation of the resultant polymer.

An alternative approach involves the use of destructible surfactants that can be converted to surface-inactive products at the end of the reaction and some examples of this approach have been reported. ${ }^{3) \sim 15)}$ Although the concept of destructible surfactant is said to facilitate the application of surfactants in organic chemistry, there are only a few reports about the practical application of such surfactants. ${ }^{6) \sim 8), 12) \sim 14)}$

We herein report on the synthesis and properties of the destructible surfactants which we have developed and found suitable for a practical emulsifier for an emulsion polymerization.

\section{Experimental}

\section{$2 \cdot 1$ Materials}

The ketones and glycerol used were all commercially available and 1,4-butanesultone was obtained from FUJI PHOTO FILM CO., LTD. .

2.2 Synthesis of 4-hydroxymethyl-1,3-dioxolane compounds $(1 \mathrm{a} \sim \mathrm{c})$

4-Hydroxymethyl-2-methyl-2- undecyl-1, 3dioxolane ( $1 \mathrm{~b}$ ) was prepared by a procedure that was used for the other hydroxymethyl-1,3-dioxolane compounds as well. In the synthesis, 100.0 $\mathrm{g}(0.50 \mathrm{~mol})$ of 2-tridecanone, $56.0 \mathrm{~g}(0.60 \mathrm{~mol})$ of glycerol, $200 \mathrm{~mL}$ of benzene, and $1.0 \mathrm{~g}$ of $p^{-}$ toluenesulfonic acid monohydrate were placed in a $500-\mathrm{mL}$ round bottom flask fitted with a DeanStark apparatus. The mixture was heated with stirring until no further separation of water occurred. The reaction mixture was cooled to room temperature, and washed successively with a $50 \mathrm{~mL}$ portion of a $5 \%$ sodium carbonate 
solution and three $50 \mathrm{~mL}$ portions of water. The benzene was removed with a rotary evaporator and the residual oil was fractionated by distillation under reduced pressure to give $118.2 \mathrm{~g}$ of product $1 \mathrm{~b}$ (yield, $86 \%$ ), bp. $140^{\circ} \mathrm{C} / 0.3 \mathrm{mmHg}$. ${ }^{1} \mathrm{H}-\mathrm{NMR}\left(\mathrm{CDCl}_{3}, \delta\right) 0.88\left(\mathrm{t}, 3 \mathrm{H}, \mathrm{CH}_{3}, J=6 \mathrm{~Hz}\right)$, $1.10 \sim 2.00\left(\mathrm{~m}, 23 \mathrm{H}, \mathrm{CH}_{2}\right.$ and $\left.\mathrm{CH}_{3} \mathrm{C}<\mathrm{O}\right)$, $3.50 \sim 4.40\left[\mathrm{~m}, 5 \mathrm{H}, \quad \mathrm{OCH}_{2} \mathrm{CH}\left(\mathrm{CH}_{2} \mathrm{O}\right) \mathrm{O}\right] . \quad \mathrm{IR}$ (neat) $3330,2920,1110,1050 \mathrm{~cm}^{-1}$

4 - Hydroxymethyl - 2 - methyl - 2 - nonyl - 1, 3 dioxolane (1 a) ; yield, $84 \%$, bp. $120^{\circ} \mathrm{C} / 0.3$ $\mathrm{mmHg}$.

${ }^{1} \mathrm{H}-\mathrm{NMR}\left(\mathrm{CDCl}_{3}, \delta\right) 0.88\left(\mathrm{t}, 3 \mathrm{H}, \mathrm{CH}_{3}, J=6\right.$ $\mathrm{Hz}), 1.10 \sim 2.00\left(\mathrm{~m}, 19 \mathrm{H}, \mathrm{CH}_{2}\right.$ and $\left.\mathrm{CH}_{3} \mathrm{C}<\mathrm{O}\right)$, $3.50 \sim 4.40\left[\mathrm{~m}, 5 \mathrm{H}, \quad \mathrm{OCH}_{2} \mathrm{CH}\left(\mathrm{CH}_{2} \mathrm{O}\right) \mathrm{O}\right]$.

IR (neat) 3330, 2920,1110, $1050 \mathrm{~cm}^{-1}$

4-Hydroxymethyl-2 - methyl-2-tridecyl-1, 3dioxolane (1 c) ; yield, $71 \%$, bp. $160^{\circ} \mathrm{C} / 0.3$ $\mathrm{mmHg}$.

${ }^{1} \mathrm{H}-\mathrm{NMR}\left(\mathrm{CDCl}_{3}, \delta\right) 0.88\left(\mathrm{t}, 3 \mathrm{H}, \mathrm{CH}_{3}, J=6\right.$ $\mathrm{Hz}), 1.10 \sim 2.00\left(\mathrm{~m}, 27 \mathrm{H}, \mathrm{CH}_{2}\right.$ and $\left.\mathrm{CH}_{3} \mathrm{C}<\mathrm{O}\right)$, $3.50 \sim 4.40\left[\mathrm{~m}, 5 \mathrm{H}, \mathrm{OCH}_{2} \mathrm{CH}\left(\mathrm{CH}_{2} \mathrm{O}\right) \mathrm{O}\right]$.

IR (neat) 3330,2920,1110, $1050 \mathrm{~cm}^{-1}$

\section{$2 \cdot 3$ Synthesis of destructible surfactants} $(2 \mathrm{a} \sim \mathrm{c})$

Sodium 4-[(2-methyl-2-undecyl-1,3-dioxolan-4-yl) methoxyl]-1-butanesulfonate (2 b) was prepared by a procedure that was used for the other surfactants as well. In this procedure, 117.2 $\mathrm{g}(0.43 \mathrm{~mol})$ of $1 \mathrm{~b}, 18.8 \mathrm{~g}(0.47 \mathrm{~mol})$ of powdered sodium hydroxide, and $200 \mathrm{~mL}$ of benzene were placed in a $500-\mathrm{mL}$ four-necked flask fitted with a sealed mechanical stirrer, a thermometer, and a condenser. The suspension was then stirred and kept at $50^{\circ} \mathrm{C}$ while $64.0 \mathrm{~g}(0.47 \mathrm{~mol})$ of 1,4 butanesultone was added for $30 \mathrm{~min}$. After the suspension was stirred at $70 \sim 75^{\circ} \mathrm{C}$ for $6 \mathrm{~h}, 500$ $\mathrm{mL}$ of ethanol was added and the mixture was filtered off at $50^{\circ} \mathrm{C}$. The solvent was removed with a rotary evaporator, and the residue was recrystallized from ethanol to give $162.0 \mathrm{~g}$ of $2 \mathrm{~b}$ (yield, 87\%).

${ }^{1} \mathrm{H}-\mathrm{NMR}\left(\mathrm{D}_{2} \mathrm{O}, \delta\right) 0.88\left(\mathrm{t}, 3 \mathrm{H}, \mathrm{CH}_{3}, J=6 \mathrm{~Hz}\right)$, $1.00 \sim 2.00\left(\mathrm{~m}, 27 \mathrm{H}, \quad \mathrm{CH}_{2}\right.$ and $\left.\mathrm{CH}_{3} \mathrm{C}<\mathrm{O}\right), 2.90$ $\left(\mathrm{t}, 2 \mathrm{H}, \mathrm{CH}_{2} \mathrm{SO}_{3}, J=7 \mathrm{~Hz}\right), 3.40 \sim 4.50(\mathrm{~m}, 7 \mathrm{H}$, $\mathrm{OCH}_{2} \mathrm{CHO}$ and $\mathrm{CH}_{2} \mathrm{OCH}_{2}$ ).

IR (KBr) 2920,1180,1110, $1050 \mathrm{~cm}^{-1}$

Anal. Calcd. for $\mathrm{C}_{20} \mathrm{H}_{39} \mathrm{O}_{6} \mathrm{NaS}: \mathrm{C}, 55.79 ; \mathrm{H}$, 9. 13.

Found: C, 55.51; H, 9.18.
Sodium 4-[(2-methyl-2-nonyl-1, 3-dioxolan4-yl)methoxy]-1-butanesulfonate (2 a); yield, $65 \%$.

${ }^{1} \mathrm{H}-\mathrm{NMR}\left(\mathrm{D}_{2} \mathrm{O}, \delta\right) 0.88\left(\mathrm{t}, 3 \mathrm{H}, \mathrm{CH}_{3}, J=6 \mathrm{~Hz}\right)$, $1.00 \sim 2.00\left(\mathrm{~m}, 23 \mathrm{H}, \mathrm{CH}_{2}\right.$ and $\left.\mathrm{CH}_{3} \mathrm{C}<\mathrm{O}\right), 2.90$ $\left(\mathrm{t}, 2 \mathrm{H}, \mathrm{CH}_{2} \mathrm{SO}_{3}, J=7 \mathrm{~Hz}\right), 3.40 \sim 4.50(\mathrm{~m}, 7 \mathrm{H}$, $\mathrm{OCH}_{2} \mathrm{CHO}$ and $\mathrm{CH}_{2} \mathrm{OCH}_{2}$ ).

IR (KBr) 2920, 1180, 1110, $1050 \mathrm{~cm}^{-1}$

Anal. Calcd. for $\mathrm{C}_{18} \mathrm{H}_{35} \mathrm{O}_{6} \mathrm{NaS}: \mathrm{C}, 53.71 ; \mathrm{H}$, 8. 76.

Found : C, 53.67; H, 8.96.

Sodium 4-[(2-methyl-2-tridecyl-1, 3-dioxolan $-4-y 1)$ methoxy]-1-butanesulfonate (2 c); yield, $75 \%$.

${ }^{1} \mathrm{H}-\mathrm{NMR}\left(\mathrm{D}_{2} \mathrm{O}, \delta\right) 0.88\left(\mathrm{t}, 3 \mathrm{H}, \mathrm{CH}_{3}, J=6 \mathrm{~Hz}\right)$, $1.00 \sim 2.00\left(\mathrm{~m}, 31 \mathrm{H}, \mathrm{CH}_{2}\right.$ and $\left.\mathrm{CH}_{3} \mathrm{C}<\mathrm{O}\right), 2.90$ $\left(\mathrm{t}, 2 \mathrm{H}, \mathrm{CH}_{2} \mathrm{SO}_{3}, J=7 \mathrm{~Hz}\right), 3.40 \sim 4.50(\mathrm{~m}, 7 \mathrm{H}$, $\mathrm{OCH}_{2} \mathrm{CHO}$ and $\mathrm{CH}_{2} \mathrm{OCH}_{2}$ ).

IR (KBr) 2920,1180,1110, $1050 \mathrm{~cm}^{-1}$

Anal. Calcd. for $\mathrm{C}_{22} \mathrm{H}_{43} \mathrm{O}_{6} \mathrm{NaS}: \mathrm{C}, 57.62 ; \mathrm{H}$, 9. 45.

Found : C, 57.44; H, 9.55.

\subsection{Surface tension measurements}

The surfactants were dissolved in $5 \mathrm{mM}$ aqueous $\mathrm{NaOH}$. Surface tension was measured with Du Nouy tensiometer (Shimadzu Model DN) at $25^{\circ} \mathrm{C}$.

\section{$2 \cdot 5$ Hydrolysis of surfactants}

The destructibility of the surfactants prepared was evaluated by being stirred in aqueous hydrochloric acid. In this procedure, $0.25 \mathrm{mmol}$ of surfactant, $40 \mathrm{mg}$ of dodecane as an internal standard for gas-liquid chromatography (GLC) and $10 \mathrm{~mL}$ of aqueous hydrochloric acid were placed in a $30-\mathrm{mL}$ Erlenmeyer flask equipped with stopper and stirred. The reaction mixture was monitored by the GLC analysis (Shimadzu GCR $1 \mathrm{~A}, \mathrm{OV}-1,1.5 \%$ on Chromosorb; $3-\mathrm{m}$ column, $150 \sim 200^{\circ} \mathrm{C}$ ) of the ketone generated.

\subsection{Polymerization procedure}

All the polymerizations were carried out under nitrogen by batch process in a $300-\mathrm{mL}$ polymerization reactor. The ingredients of the polymerization batches are shown in Table-3. The reaction mixture was stirred and thermostatted at $10^{\circ} \mathrm{C}$. After the reaction was complete, the latex polymer was precipitated with hydrochrolic acid $(\mathrm{pH} 1.0)$ or acetic acid $(\mathrm{pH} 1.0)$ at $80^{\circ} \mathrm{C}$. The precipitate obtained was filtered, washed successively with water, and dried under reduced 
pressure at $60^{\circ} \mathrm{C}$ for $10 \mathrm{~h}$.

\section{Results and Discussion}

Surfactants were prepared by the sequence outlined in Scheme-1. Acid-catalyzed condensation of glycerol with 2 -pentadecanone, 2 tridecanone, or 2-undecanone, afforded the appropriate 1,3-dioxolane compound $(1 \mathrm{a}-\mathrm{c})$. When ketones condense with glycerol, the 4hydroxymethyl-2,2-disubstituted-1,3-dioxolane is only obtained ${ }^{16)}$. The products reacted with 1,4 -butanesultone in the presence of sodium hydroxide to yield sulfonate compounds. The reaction was carried out in benzene solution at 50 to $70^{\circ} \mathrm{C}$. The sulfobutylated 1,3-dioxolane compounds could be recrystallized from ethanol solution to give destructible anionic surfactants $(2 \mathrm{a}-\mathrm{c})$ in good yield as shown in Table-1.

All surfactants obtained were readily soluble in water at room temperature, and lowered surface tension satisfactorily. The surface tension at $25^{\circ} \mathrm{C}$ was plotted against the logarithm of the concentration, as shown in Fig. -1 . The curves

$$
\begin{aligned}
& \begin{array}{c}
\mathrm{R}-\mathrm{C}-\mathrm{CH}_{3} \\
\stackrel{\mathrm{O}}{I}
\end{array}+\underset{\substack{\mathrm{C} \\
\mathrm{C}}}{\stackrel{\mathrm{C}}{\mathrm{C}} \mathrm{H}_{2} \mathrm{OH}}
\end{aligned}
$$

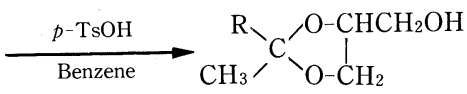

$$
\begin{aligned}
& 1 \mathrm{a}, \mathrm{b}, \mathrm{c}
\end{aligned}
$$

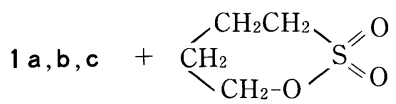

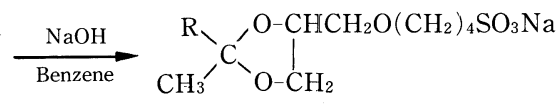

$$
\begin{aligned}
& 2 a, b, c \\
& \mathrm{R}=\stackrel{\stackrel{\mathbf{a}}{\mathrm{C}}}{\mathrm{H}_{19}}, \stackrel{\stackrel{b}{\mathrm{~b}}}{\mathrm{C}_{11}} \stackrel{\stackrel{\mathbf{H}}{\mathrm{H}_{23}},}{\mathrm{C}_{13} \mathrm{H}_{27}}
\end{aligned}
$$

Scheme-1

Table-1 Synthesis of compound $1 \mathrm{a}-\mathrm{c}$ and $2 \mathrm{a}-\mathrm{c}$

\begin{tabular}{c|c|c|c}
\hline Compound & Yield (\%) & Compound & Yield (\%) \\
\hline $1 \mathbf{a}$ & 84 & $2 \mathbf{a}$ & 65 \\
$1 \mathbf{b}$ & 86 & $2 \mathbf{b}$ & 87 \\
$1 \mathbf{c}$ & 71 & $2 \mathbf{c}$ & 75 \\
\hline
\end{tabular}

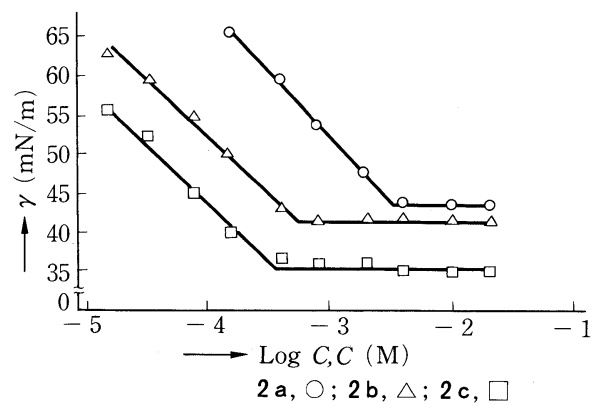

Fig.-1 Surface tension $(\gamma)$ s. log molar concentration for $2 \mathrm{a}, \mathrm{b}$ and $\mathrm{c}$.

had inflection points, and the surface activity of these surfactants increased with increasing the length of the alkyl chain.

In order to estimate the destructibility of these surfactants, the surfactants were stirred in aqueous hydrochloric acid. The results of examination of the destructibility are shown in Table-2. They were easily hydrolyzed under mild acidic conditions. Compounds $2 \mathrm{a}$ and $2 \mathrm{~b}$ completely decomposed within $2 \mathrm{~h}$ in $0.05 \mathrm{M} \mathrm{HCl}$, and compound $2 \mathrm{c}$ was most stable to hydrolysis among the destructible surfactants. According to the earlier paper ${ }^{15)}$, the acidic hydrolysis rate of anionic surfactants containing a ketal group is greater than that of the corresponding cationic or nonionic surfactants. As expected, these anionic surfactants is much more cleavable than the cationic or nonionic surfactants reported in our previous papers ${ }^{13), 14}$. For example, Compound 2 b completely decomposed within $15 \mathrm{~min}$ in $0.5 \mathrm{M}$ $\mathrm{HCl}$, whereas the cationic and nonionic surfac-

Table-2 Destructibility of surfactants with a 1,3-dioxolane ring.

\begin{tabular}{c|l|c|c|c}
\hline Compound & $\begin{array}{c}\mathrm{HCl}_{\mathrm{aq}} \\
(\mathrm{M})\end{array}$ & $\begin{array}{c}\text { Temp. } \\
\left({ }^{\circ} \mathrm{C}\right)\end{array}$ & $\begin{array}{c}\text { Time } \\
(\mathrm{h})\end{array}$ & $\%$ dec \\
\hline 2 b & 0.5 & 25 & 0.25 & 100 \\
$2 \mathbf{b}$ & 0.1 & 25 & 2 & 100 \\
$2 \mathbf{b}$ & 0.05 & 25 & 2 & 100 \\
$2 \mathbf{b}$ & 0.01 & 25 & 3 & 100 \\
$2 \mathbf{b}$ & 0.005 & 25 & 3 & 100 \\
$2 \mathbf{b}$ & 0.001 & 25 & 10 & 100 \\
$2 \mathbf{b}$ & 0.005 & 35 & 2 & 100 \\
$2 \mathbf{b}$ & 0.005 & 45 & 1.5 & 100 \\
$2 \mathbf{a}$ & 0.05 & 25 & 2 & 100 \\
$2 \mathbf{c}$ & 0.05 & 25 & 2 & 72 \\
\hline
\end{tabular}


Table-3 Recipes for emulsion polymerizations used*

\begin{tabular}{l|c|c|c|c|c}
\hline \multirow{2}{*}{\multicolumn{1}{c|}{ Ingredient }} & \multicolumn{5}{c}{ Reaction system } \\
\cline { 2 - 6 } & $\mathrm{A}$ & $\mathrm{B}$ & $\mathrm{C}$ & $\mathrm{D}$ & $\mathrm{E}$ \\
\cline { 2 - 6 } & \multicolumn{5}{|c|}{ Amount (parts by weight) } \\
\hline Butadiene & 65 & 65 & 65 & 65 & 65 \\
Acrylonitrile & 35 & 35 & 35 & 35 & 35 \\
Compound 2 b & 2 & 4 & 6 & 4 & 0 \\
Sodium dodecylbezenesulfonate & 0 & 0 & 0 & 0 & 2 \\
1-Dodecanethiol & 0.45 & 0.45 & 0.45 & 0.45 & 0.45 \\
Tetrasodium EDTA & 0.02 & 0.02 & 0.02 & 0 & 0 \\
Iron (II) sulfate & 0.01 & 0.01 & 0.01 & 0 & 0 \\
Sodium formaldehydesulfoxylate & 0.05 & 0.05 & 0.05 & 0 & 0 \\
Paramenthane hydroperoxide & 0.04 & 0.04 & 0.04 & 0 & 0 \\
Ammonium persulfate & 0 & 0 & 0 & 1 & 1 \\
Water & 200 & 200 & 200 & 200 & 200 \\
\hline
\end{tabular}

* A, B and C were at $10^{\circ} \mathrm{C} . \mathrm{D}$ and $\mathrm{E}$ were at $60^{\circ} \mathrm{C}$.

tants having the same alkyl chain were required 18 $\mathrm{h}$ and $3 \mathrm{~h}$ for their cleavage, respectively ${ }^{14}$.

Surfactants are very extensively used in the production of polymers in emulsion systems. For the purpose of investigating the property of obtained polymers depend upon the type of surfactant, compound $2 \mathrm{~b}$ was used as an emulsifier in emulsion copolymerization of butadiene and acrylonitrile monomers. In the investigation reported in this paper, five reaction systems were used. Four of these (Reaction system A, B, C, and D) were for the emulsion copolymerization with varying destructible surfactant concentrations. The fifth reaction system (Reaction system E) was a conventional emulsion copolymerization reaction system which contained sodium dodecylbenzenesulfonate as an emulsifier. The formulation for the five reaction systems are summarized in Table-3.

These reaction systems produced butadieneacrylonitrile copolymers except for the reaction system D. The failure of polymerization for the reaction system $D$ is attributed to the hydrolysis of the surfactant ( $2 \mathrm{~b}$ ) used at the low $\mathrm{pH}$ of the reaction system using ammonium persulfate as an initiater. The levels of the ash content of the polymers obtained are determined (Table-4). The results show that the use of the destructible surfactant can lower the ash content of the resulting polymer. This is because the emulsion produced by using the destructible surfactant
Table-4 Analysis of reaction products

\begin{tabular}{c|c}
\hline Reaction system & Ash content (\%) \\
\hline B $^{*}$ & 0.14 \\
B $^{* *}$ & 0.13 \\
E & 0.30 \\
\hline
\end{tabular}

* Reaction product was precipitate with $\mathrm{HCl}$.

** Reaction product was precipitate with acetic acid.

needs no addition of an appropriate metal salt for its emulsion breaking and the resulting polymer is estimated to contain very little quantity of surfactant since the destructible surfactant is decomposed by acid.

\section{Conclusion}

The work described in this paper is a synthetic method and characteristics of destructible surfactants containing a ketal and sulfonate group. They had good surface activity, and were more readily decomposed under acidic conditions compared to corresponding cationic or nonionic surfactants. In addition, the use of the destructible surfactant as emulsifier for emulsion polymerization presented a production of polymers which reduced the ash content of them.

(Received March 22, 1991)

\section{References}

1) J. H. Fendler and E. J. Fendler, "Catalysis in Micellar and Macromolecular" , Academic 
Press, New York (1975).

2) W.P. Weber and G.W. Gokel, "Pase Transfer Catalysis in Organic Synthesis”, Springer-Verlag KG, Berlin (1977).

3) J. Cuomo, J.H. Merrifield, and J.F.W. Keana, J. Org. Chem., 45, 4216 (1980).

4) B. Burczyk and L. Weclas, Tenside Deterg., 17, 21 (1980).

5) L. Weclas and B. Burczyk, Tenside Deterg. , 18, 19 (1981).

6) D. A. Jaeger and M. R. Frey, J. Org. Chem., 47, 311 (1982).

7) D. A. Jaeger and M. D. Ward, J. Org. Chem., 47, 2221 (1982).

8) J.F.W. Keana, A. P. Guzikowski, C. Morat, and J. J. Volwerk, J. Org. Chem., 48, 2661 (1983).

9) Y. Hayashi, F. Shirai, T. Shimizu, Y. Nagano, and K. Teramura, J. Am. Oil Chem. Soc., 62, 555 (1985).

10) T. Nyudo, K. Nakao, and E. Minami, Yukagaku, 28, 909 (1979).

11) T. Kuwamura and H. Takahashi, Bull. Chem. Soc. Jpn., 45, 617 (1972).

12) G. Messwarb, E. Pashke, and P. Seibel. Angew. Chem., 71, 604 (1959).

13) S. Yamamura, M. Nakamura, and T. Takeda, J. Am. Oil Chem. Soc., 66, 1165 (1989).
14) S. Yamamura, M. Nakamura, K. Tanaka, and T. Takeda, J. Jpn. Oil. Chem. Soc. (Yukagaku), 40, 104 (1991).

15) D. Ono, A. Masuyama, and M. Okahara, $J$. Org. Chem., 55, 4461 (1990).

16) A. J. Showler and P.A. Darley, Chem. Rev., 67, 427 (1967).

1, 3-ジオキソラン環を持つ分解性アニオン 界面活性剂の合成と性質及び 乳化重合への応用

山村伸吾* . 中村正樹* · 笠井 澄**. 佐藤穂積 $* *$ 武田徳司 $*$

* 大阪市立工業研究所 ( $\overline{7} 536$ 大阪市城東区森/宮 1-6-50)

**日本合成ゴム株式会社エマルション開発研究所 ( テ510 四日市市川尻町 100)

1,3-ジオキソラン環を持つアニオン界面活性剤の合成 を行い, その表面張力低下能を測定した。これらの界面 活性剂は, 親水基にスルホナート基を有しており, 酸性 条件下, 以前合成したカチオン型や非イオン型のものよ り容易に分解する性質を持つことが分かった。また，乳 化重合の乳化剂として使用すると, 従来の乳化重合では 得られない低金属含有量のポリマーが得られた。 